\title{
A Study on the Differences in the Quality of Life of Divorce in Old Age
}

\author{
Boo-Hwan $\mathrm{Ahn}^{1}$ and Yun-Jeong Kim ${ }^{2}$ \\ ${ }^{1}$ Department of Elderly Welfare, Hanseo University, Doctor, Republic of Korea \\ ${ }^{2}$ Department of Heath, Counseling and Welfare, Hanseo University, Professor, \\ Republic of Korea \\ 1'daebart@hanmail.net, ${ }^{2}$ twoyun21@hanmail.net
}

\begin{abstract}
The purpose of this study was to understand the difference in quality of life between the divorced elderly and the married elderly by using the 14th-year data of Korea Welfare Panel 2019. More concretely, first, this study analyzed differences in the quality of life (physical health, psychological health, economic health, social relation) between divorced elderly and married elderly. To achieve the objective of this study, this study targeted total 3,572 elderly people (286 divorced elderly, 3,286 married elderly) in their 60 or up in the 14th-year data of Korea Welfare Panel. Using the SPSS Win 21.0 ver., this study applied the frequency, reliability, $t$-test, cross tab. The whole 286 divorced elderly were composed of women $(52.4 \%)$ and men (47.6\%), so that women were a bit more than men. In the age of divorced elderly, the elderly in 60-69(60.8\%) were the most, which was followed by the elderly in 70-79(31.8\%) and the elderly in 80 or up (7.3\%) in order. In the academic background, the graduation from elementary school or lower (40.6\%) was the most, which was followed by graduation from high school or higher (32.9\%) and graduation from middle school (26.6\%) in order. As a result, the quality of life of the divorced elderly was lower than the one of the married elderlies. In other words, the divorced elderly smoked more, had lower self-esteem, and showed the lower household income and lower satisfaction with family income than the married elderly.
\end{abstract}

Keywords: Divorce in old age, Quality of life after divorce, Differences in the quality of life

\section{Introduction}

\subsection{Necessities of research}

The divorce rate of elderly women in their 60 or up was also constantly increasing from $1.0 \%$ in 2009 to $1.8 \%$ every year. This is the highest rate since the relevant records began in 1970 [1]. In other words, the divorce rate is increasing in middle/old-aged couples who have continued their marriage for a considerable period of time.

This phenomenon is because they choose a happy divorce rather than maintaining an unhappy marriage as ordinary people's attitude toward divorce in old age has been changed a lot [2]. Also, they choose to marry after their children are grown up a bit or get married, which is in the same context with the divorce at Narita International Airport of Japan. Nevertheless, the divorce in the time when interpersonal relationships are reduced, has huge positive or

Article history:

Received (December 8, 2020), Review Result (January 12, 2021), Accepted (March 9, 2021) 
negative effects on the life quality of old age. The quality of life would be examined by dividing it into physical health, psychological health, economic health, and social health.

Like this, there have been many researches on the relation between divorce and quality of life in subdivision. Nevertheless, the existing Korean researches, first, mostly target the divorced women, which is a limitation, and second, target a group of adults or conduct a research with no limitation of age. In other words, even though there are some researches on the experience of adapting to divorce in each age group [2][3] the research participants are the divorced men and women in their 20s-30s, so that they do not handle the divorce of the elderly which is rapidly increasing.

Thus, in order to secure the reliability of data by using the Korea Welfare Panel Data, and to understand the quality of life of the divorced elderly as compared to the married elderly, this study examined the differences in the quality of life between divorced elderly and married elderly. Of course, the marital relationship plays both positive and negative roles in human beings through daily life. However, they chose to divorce even though they already perceived the fact that the life after divorce would be difficult after living together for a long time, and that the negative influence and ripple effect of divorce in old age would be greater than other age groups when the social resources were decreasing. Thus, this study also aims to understand the variables having effects on the matter of divorce in old age.

\subsection{Purpose}

The objective of this study was to understand differences in the lives of the divorced elderly and the married elderly, by analyzing differences in the quality of life (physical health, psychological health, economic health, social relationship) between divorced elderly and married elderly, by using the 14th-year data of Korea Welfare Panel 2019.

\section{Method}

\subsection{Data}

This study used the data of 3,572 elderly people in their 60 or up in the 14th-year data of Korea Welfare Panel 2019 [4]. As a longitudinal research targeting the whole nation including Jeju-do, the Korea Welfare Panel is researched every year by selecting total 7,000 households including 3,500 low-income households and 3,500 ordinary households through the stratified cluster systematic sampling, referring to the Population and Housing Census, and the Survey on the National Living Conditions. The Korea Welfare Panel has secured the nation-wide representativeness by including various types of households even including farming and fishing villages in small towns and townships. On the basis of 2019, there were 286 divorced elderly in their 60 or up in divorced state, and 3,286 married elderly in their 60 or up with a spouse.

\subsection{Measurement}

The variables selected to achieve the objective of this study are as [Table 1], and the higher score means the higher tendency.

Table 1. Definition and measurement method of variables

\begin{tabular}{|c|c|c|c|}
\hline \multicolumn{2}{|c|}{ Variable name } & Measurement method & Cronbach's alpha \\
\hline Dependent variable & Marital status & Divorced elderly=1, Married & \\
\hline
\end{tabular}




\begin{tabular}{|c|c|c|c|}
\hline & & elderly $=0$ & \\
\hline \multirow{4}{*}{$\begin{array}{l}\text { Sociodemographic } \\
\text { characteristics }\end{array}$} & Gender & Men $=1$, Women $=2$ & \\
\hline & Age & $\begin{array}{c}60 \mathrm{Y} \sim 69 \mathrm{Y}=1,70 \mathrm{Y} \sim 79 \mathrm{Y}=2,80 \mathrm{Y} \text { or } \\
\text { up=3 }\end{array}$ & \\
\hline & Academic background & $\begin{array}{c}\text { Graduation from elementary school } \\
\text { or lower=1, Graduation from } \\
\text { middle school=2, Graduation from } \\
\text { high school or higher=3 }\end{array}$ & \\
\hline & Religion & No religion $=0$. Having religion $=1$ & \\
\hline \multirow{4}{*}{ Physical health } & $\begin{array}{l}\text { Subjective health } \\
\text { status }\end{array}$ & $\begin{array}{c}\text { Single item: } 1 \text { (Very bad }) \sim 5(\text { Very } \\
\text { good })\end{array}$ & \\
\hline & Chronic disease & $\begin{array}{c}\text { Less than } 3 \text { months }=1,3 \sim 6 \\
\text { months }=2,6 \text { months or more }=3\end{array}$ & \\
\hline & Smoking & No smoking $=0$, Smoking $=1$ & \\
\hline & Drinking & No drinking $=0$, Drinking $=1$ & \\
\hline \multirow[t]{2}{*}{ Psychological health } & Depression & $\begin{array}{l}\text { CES-D (Center for Epidemiologic } \\
\text { Studies- } \\
\text { Depression Scale) short-form scale. } \\
1 \text { (low) } \sim 4 \text { (high) }\end{array}$ & .983 \\
\hline & Self-esteem & $\begin{array}{l}\text { Rosenberg's self-esteem. } \\
\qquad: 1 \text { (low) } \sim 4 \text { (high) }\end{array}$ & .951 \\
\hline \multirow{4}{*}{ Economic health } & Household income & Current income(unit:10,000won) & \\
\hline & $\begin{array}{l}\text { Satisfaction with } \\
\text { family income }\end{array}$ & $\begin{array}{c}\text { Single item: } 1(\text { very dissatisfied }) \sim \\
5(\text { very satisfied })\end{array}$ & \\
\hline & $\begin{array}{l}\text { Type of working } \\
\text { hours }\end{array}$ & Part-time $=1$, Full-time $=2$ & \\
\hline & Public pension & Unregistered $=1$, Registere $=0$ & \\
\hline \multirow{4}{*}{ Social relationship } & $\begin{array}{l}\text { Satisfaction with } \\
\text { family life }\end{array}$ & $\begin{array}{c}\text { Single item: } 1 \text { (very dissatisfied }) \sim \\
7(\text { very satisfied })\end{array}$ & \\
\hline & $\begin{array}{l}\text { Satisfaction with } \\
\text { children }\end{array}$ & $\begin{array}{c}\text { Single item: } 1 \text { (very dissatisfied }) \sim \\
7(\text { very satisfied })\end{array}$ & \\
\hline & Family conflict & $\begin{array}{l}\text { Totaled mean of four items such as } \\
\text { 'disagreement, throwing objects, } \\
\text { criticism, and assault': 1(not at all) } \\
\sim 5 \text { (very much likely) }\end{array}$ & .819 \\
\hline & $\begin{array}{l}\text { Satisfaction with } \\
\text { social relationship }\end{array}$ & $\begin{array}{l}\text { Single item: } 1 \text { (very dissatisfied }) \sim \\
5(\text { very satisfied })\end{array}$ & \\
\hline
\end{tabular}




\subsection{Analysis method}

Using the SPSS Win 21.0 version, this study applied the frequency, reliability, t-test, cross tab.

\subsection{Sociodemographic characteristics of research subjects}

The whole 286 divorced elderly were composed of women (52.4\%) and men (47.6\%), so that women were a bit more than men. In the age of divorced elderly, the elderly in 60$69(60.8 \%)$ were the most, which was followed by the elderly in 70-79(31.8\%) and the elderly in 80 or up $(7.3 \%)$ in order. In the academic background, the graduation from elementary school or lower $(40.6 \%)$ was the most, which was followed by graduation from high school or higher $(32.9 \%)$ and graduation from middle school $(26.6 \%)$ in order.

Also, the whole 3,286 married elderly were composed of men (53.2\%) and women (46.8\%), so that there were more men than women. In the age of married elderly, the elderly in 70$79(43.0 \%)$ were the most, which was followed by the elderly in 60-69(39.9\%) and the elderly in 80 or up $(17.1 \%)$ in order. In the academic background, the graduation from elementary school or lower (44.9\%) was the most, which was followed by graduation from high school or high $(32.6 \%)$ and graduation from middle school (22.5\%) in order.

\section{Results}

\subsection{Differences in the quality of life between divorced elderly and married elderly}

The differences in the quality of life (physical health, psychological health, economic health, social relation) between divorced elderly and married elderly were presented in Table 2 and Table 3, and only the results showing significant differences were presented in tables.

The divorced elderly smoked more and had lower self-esteem than the married elderly. Also, the divorced elderly had lower household income and lower satisfaction with family income than the married elderly. In case of public pension, the divorced elderly showed the lower registration rate than the married elderly.

Regarding the social relation, all the satisfaction with family life, satisfaction with children, family conflict, and satisfaction with social acquaintance relationship showed significant differences between two groups. All the satisfaction with family life, satisfaction with children, family conflict, and satisfaction with social acquaintance relationship were lower in the divorced elderly than the married elderly.

Table 2. Differences in the quality of life $1(\mathrm{~N}=3,572)$ Mean (S.D)

\begin{tabular}{|c|c|c|c|c|c|c|}
\hline \multicolumn{3}{|c|}{ Marital status } & $\mathrm{N}$ & M & S. D & $\mathrm{t}$ \\
\hline \multirow{2}{*}{$\begin{array}{c}\text { Psychological } \\
\text { health }\end{array}$} & \multirow{2}{*}{ Self-esteem } & Divorced & 282 & 3.35 & .580 & \multirow{2}{*}{$-6.017^{*}$} \\
\hline & & Married & 3,162 & 3.69 & .932 & \\
\hline \multirow{4}{*}{$\begin{array}{l}\text { Economic } \\
\text { health }\end{array}$} & \multirow{2}{*}{$\begin{array}{l}\text { Household } \\
\text { income }\end{array}$} & Divorced & 286 & 2198.78 & 2328.657 & \multirow{2}{*}{$-9.528^{* * * *}$} \\
\hline & & Married & 3,286 & 3608.80 & 3109.105 & \\
\hline & \multirow{2}{*}{$\begin{array}{c}\text { Satisfaction with } \\
\text { family income }\end{array}$} & Divorced & 281 & 2.67 & .882 & \multirow{2}{*}{$-4.818^{* * * *}$} \\
\hline & & Married & 3,082 & 2.94 & .839 & \\
\hline Social & Satisfaction with & Divorced & 282 & 4.05 & 1.995 & $-10.513^{* * * *}$ \\
\hline
\end{tabular}




\begin{tabular}{|c|c|c|c|c|c|c|}
\hline \multirow[t]{7}{*}{ relationship } & family life & Married & 3,162 & 5.33 & 1.316 & \\
\hline & \multirow{2}{*}{$\begin{array}{c}\text { Satisfaction with } \\
\text { children }\end{array}$} & Divorced & 282 & 3.96 & 2.238 & \multirow{2}{*}{$-10.849^{* * *}$} \\
\hline & & Married & 3,162 & 5.44 & 1.443 & \\
\hline & \multirow{2}{*}{ Family conflict } & Divorced & 286 & 1.15 & .701 & \multirow{2}{*}{$-3.970^{* * *}$} \\
\hline & & Married & 3,286 & 1.32 & .457 & \\
\hline & \multirow{2}{*}{$\begin{array}{c}\text { Satisfaction with } \\
\text { social } \\
\text { relationship }\end{array}$} & Divorced & 281 & 3.49 & .718 & \multirow[b]{2}{*}{$-5.208^{* * *}$} \\
\hline & & Married & 3,082 & 3.72 & .650 & \\
\hline
\end{tabular}

${ }^{*} p<.05, \stackrel{* * *}{p}<.001$

Table 3. Differences in the quality of life $2(\mathrm{~N}=3,572), \mathrm{N}(\%)$

\begin{tabular}{|c|c|c|c|c|c|}
\hline & & & \multicolumn{2}{|c|}{ Marital status } & \multirow{2}{*}{ chi-square } \\
\hline & & & Divorced & Married & \\
\hline \multirow{2}{*}{$\begin{array}{l}\text { Physical } \\
\text { health }\end{array}$} & \multirow{2}{*}{ Smoking } & No smoking & $\begin{array}{c}219 \\
(77.7)\end{array}$ & $\begin{array}{l}2,838 \\
(89.8)\end{array}$ & \multirow{2}{*}{$37.966^{* * *}$} \\
\hline & & Smoking & $\begin{array}{c}63 \\
(22.3)\end{array}$ & $\begin{array}{c}324 \\
(10.2)\end{array}$ & \\
\hline \multirow{2}{*}{$\begin{array}{l}\text { Economic } \\
\text { health }\end{array}$} & \multirow{2}{*}{ Public pension } & Unregistered & $\begin{array}{c}192 \\
(67.1)\end{array}$ & $\begin{array}{l}1,836 \\
(55.9)\end{array}$ & \multirow{2}{*}{$13.591^{* * *}$} \\
\hline & & Registered & $\begin{array}{c}94 \\
(32.9)\end{array}$ & $\begin{array}{l}1,450 \\
(44.1)\end{array}$ & \\
\hline
\end{tabular}

${ }^{* * *} p<.001$

\section{Discussion}

The objective of this study was to understand differences in the lives of the divorced elderly and the married elderly, by analyzing differences in the quality of life (physical health, psychological health, economic health, social relation) between divorced elderly and married elderly. To achieve the objective of this study, this study targeted total 3,572 elderly people (286 divorced elderly, 3,286 married elderly) in their 60 or up in the 14th-year data of Korea Welfare Panel.

The results of this study could be summarized and discussed as follows. The quality of life of the divorced elderly was lower than the one of the married elderlies. In other words, the divorced elderly smoked more, had lower self-esteem, and showed the lower household income and lower satisfaction with family income than the married elderly. As their registration rate of public pension was also lower, the life of old age in the future is predicted to be unstable. Also, the divorced elderly showed the lower satisfaction with family life, lower satisfaction with children, and lower satisfaction with social acquaintance relationship than the married elderly. 
Such results of this study are in the same context with many preceding researches $[5][6][7][8][9][10][11]$ reporting that the life of quality gets poor after divorce.

Like this, the deteriorated quality of life after divorce could be interpreted with the marital relation crisis model. In the crisis model, the stress and tension by the process of marital dissolution such as divorce or bereavement are regarded as having negative effects on the health. It was explained that the social prejudice, economic/socio-emotional loss, and environmental changes like movement of residence by marital dissolution like divorce would have negative effects on the quality of life [12].

Also, in differences between divorced elderly and married elderly, the household income of the divorced elderly was lower. In the logistic regression analysis, when the household income got higher, the possibility of belonging to the group of divorced people got higher. In this result, when the financial ability of family is increased, the cost for divorce could be provided, which could increase the possibility of divorce [13]. Nevertheless, this result indirectly shows that the economic condition gets difficult after divorce.

\section{Acknowledgments}

This study was funded by a fund for graduate students at Hanseo University.

\section{References}

[1] National Statistical Office (KOSTAT), "2019 marriage and divorce statistics," http://www.index.go.kr /potal/main/EachDtlPageDetail.do?idx_cd=1579, Oct 5 (2020)

[2] S. W. Ok and S. Y. Kwon, "Predictors of post-divorce adjustment -among divorced men and women in their 20s and 30s," Family and Environment Research, vol.43, no.3, pp.199-219, (2005)

[3] M. A. Sung and S. W. Ok, "Qualitative research on women's post-retirement lives," Family and Culture, vol.16, no.2, pp.55-91, (2004)

[4] Korea Welfare Panel Study, https://www.koweps.re.kr:442/main.do, Oct 5 (2020)

[5] M. L. Frisco and K. Williams, "Perceived housework equity, marital happiness, and divorce in dual-earner households," Journal of Family Issues, vol.24, no.1, pp.51-73, (2003)

[6] D. N. Hawkins and A. Booth, "Unhappily ever after: Effects of long-term, low-quality marriages on well-being," Social Forces, vol.84, no.1, pp.451-471, (2005)

[7] E. K. Jang and H. J. Choi, "Divorce and physical health among older individuals - self-esteem and depressive symptoms as mediators and gender as a moderated mediator," The Korean Home Management Association, vol.37, no,3, pp.55-72, (2019)

[8] H. Y. Kim, "Trends and causes of subjective well-being in Korea: Focusing on differences by gender and age," Korea Association for Policy Sciences, vol.24, no.2, pp.47-72, (2020)

[9] L. A. Lillard and L. J. Waite, "Till death do us part: Marital disruption and mortality," American Journal of Sociology, vol.100, no.5, pp.1131-1156, (1995)

[10] P. Diedrick, "Gender differences in divorce adjustment," Journal of Divorce and Remarriage, vol.14, no.3-4, pp.33-46, (1991)

[11] E. J. Kim and C. B. Joo, "The influence of senior employment program on the wellbeing of the elderly," Korea Public Administration Quartely, vol.31, no.2, pp.307-325, (2019)

[12] D. Umberson and C. L. Williams, "Divorced fathers: Parental role strain and psychological distress," Journal of Family Issues, vol.14, no.3, pp.378-400, (1993)

[13] S. S. Bang and B. I. Jang, "Social welfare approach for divorce increase," Journal of Public Welfare Administration, vol.13, no. 1, pp. 160-175, (2003) 